\title{
Edmonton Max
}

dmonton Institution is known as the worst and most corrupt prison Cin Canada, not only amongst its prisoners, but its staff as well. This reputation is evidenced by multiple disparaging news articles, as well as numerous lawsuits directed towards Edmonton Institution. Throughout this piece, I will reinforce the reality of this unfortunate truth through discussions of the plethora of issues present in Edmonton Institution based not only my own experiences, but also those of my fellow prisoners.

Due to COVID-19, prisoners have been subjected to a modified routine. We have complied with the mandates changes in order to avoid contracting the virus and prevent its spread within the institution. Commissioner Anne Kelly stated in a previous memo that soap and hand sanitizer would be provided. However, as I write in the spring, we have yet to be offered either. Additionally, since the suspension of visits and programming, the only possible way for prisoners to contract COVID-19 is from CSC staff, some of whom neglect our safety by not wearing masks during walks.

Following a CBC News article exposing Edmonton Institution staff for ignoring the seriousness of this global pandemic, CSC sent one prisoner up the Parole Board of Canada for a detainment order. This is an arbitrary and completely disproportionate response for a first-time federal prisoner known by all to have zero institutional charges and to be observing his correctional plan. Is this not what we all should be doing as we work to become law-abiding citizens? Punishing someone for exercising their freedom of expression is unlawful and undermines the very thing CSC emphasizes us to do the most - respect the law.

Here in Edmonton Institution, there is a severe lack of programming and schooling opportunities, thereby hindering our potential for rehabilitation. For instance, a fellow prisoner who is serving a life sentence told me that he is constantly inquiring about receiving programming, yet has never been offered any in all the years he has been here. Schooling within the institution is problematic. Each unit only has access to the classroom and teacher once a week (if we are not locked down) for a few hours and only six prisoners per range can enroll.

When the kitchen prepares our food, they load our trays into a heated serving cart. However, our trays usually arrive on the unit a half hour before meal times, which means our food is already cold by the time we 
are allowed to consume them. The units here used to have two industrial microwaves each for servers to re-heat the meals if necessary. However, the industrial microwaves were replaced with household versions which created unnecessary extra work for the servers because the new microwaves are not capable of reheating multiple meals simultaneously.

Edmonton Institution does not provide perishable canteen items. The product list consists of mainly junk food that can be found at the corner store. Healthy alternative options are lacking. Upon inquiry into this issue, we are told the institution does not have the means to acquire an industrial size freezer or fridge to store such items. It is unfair for prisoners residing here not to be provided the same selection that prisoners elsewhere have access to.

In the Edmonton Institution prisoner handbook, it states that prisoners are encouraged to work closely with staff members in developing and following our correctional plan. This is challenging due to constant staff mistreatment and the lack of adequate communication with our parole officers. We feel like we are left in the dark because parole officers rarely come in to discuss anything with their assigned prisoners. Staff constantly abuse their power of authority by repeatedly punishing and belittling prisoners, rather than aiding in our rehabilitation.

While maximum-security institutions are mandated to attempt to give their prisoners opportunities to cascade down to medium security institutions, Edmonton Institution is known for "warehousing" prisoners. I am personally aware of a prisoner who has been rated as medium-security for a year, yet he continues to reside in Edmonton Institution.

Due to staff negligence, prisoners are left no other alternative but to voice their concerns through peaceful protest. However, staff will purposefully mischaracterize and document these peaceful protests as incidents, impeding any application of participating prisoners to a medium-security facility. Peaceful protests and unit-based activities should not be considered incidents because if someone chooses not to participate, this will jeopardize the safety of the said person.

In summary, I have yet to meet a prisoner or even staff member that will disagree with the fact that Edmonton Institution is the worst federal institution in the country. The issues discussed above only scratch the surface of problems related to this institution. Ultimately, Edmonton Institution is solely focused on furthering the punishment of prisoners, which is contrary 
to the Correctional Service of Canada's mission statement of encouraging rehabilitation so that we can become law-abiding citizens upon release.

\section{ABOUT THE AUTHOR}

This author remains anonymous. 